\title{
The Implementation of Right-Fulfillment to the Education of Elementary School Students in the COVID- 19 Pandemic Situation
} \author{
| Harisman ${ }^{1, *} \mid$ M. Syukr
1,2,3Faculty of Law, Universitas
Muhammadiyah Sumatera \\ Utara, Indonesia
}

*harisman@umsu.ac.id
DOI: https://doi.org/10.47175/rissj.v2i4.328

\begin{abstract}
This study is intended to explain the legal protection given to elementary school children to get the right to education during the COVID 19 period. Because education for children is a child's right that must be fulfilled as a human right. Moreover, the right to education has been explicitly guaranteed in the Amendment to the 1945 Constitution. For this reason, legal research is carried out with an empirical juridical approach which intends to study and analyze the workings of law in society by using secondary data and primary data. The secondary and primary data collected were analyzed qualitatively, then the results were described. Based on an analysis conducted on research conducted in Firdaus Village, Serdang Bedagai Regency, that the right to education for elementary school children during the COVID 19 period was still being fulfilled despite the prohibition on conducting face-to-face learning processes at schools. The implementation of education is carried out through distance learning meetings in the network and distance learning outside the network. In addition, it was also found that there was limited face-to-face learning. However, the use of this learning method takes into account the development of the COVID-19 situation and also the facilities owned by schools, teachers and the condition of students in participating in learning. Schools and teachers evaluate children's education to determine the learning process that will be used. KEYWORDS

The Implementation of Right-Fulfillment to Children Education; Elementary School; COVID 19
\end{abstract}

\section{INTRODUCTION}

Appearance of COVID19 pandemic in early 2020 greatly affected various aspects of people's lives. The existence of COVID19 (Corona Virus Diseases 2019) is very worrisome and has a huge impact on the global communit (Andriando et al, 2021). This pandemichasimpacted people's lives inthe social, economic, and educational fields. One of the sectors affected is the education sector. Schools and universities have been closed in several countrieswhere the people areinfected with COVID-19 (Fuady et al, 2021). Moreover, the government with its legal policies that limit the movement of people through the implementation of Large-Scale Social Restrictions (abbreviated as PSBB) and or the Enforcement of Restrictions on Community Activities (abbreviated as PPKM) as one of the steps to overcome and reduce the spread of COVID-19. Government policies like this, do not escape This has an impact on school activities, because Based on Article 4 (1) of the 2020 Government Ordinance No. 21 on Massive Social Restrictions Related to 
Acceleration of Confectionery with Coronavirus Disease 2019 (COVID-19), it is seen that the implementation of PSBB is one of the targets applied to schools.

The existence of provisions like this is intended to break the chain of spread COVID-19 starting from the school environment. Because schools are one of the areas that have a risk as a gathering place for people so that they are considered to have the potential to transmit COVID-19. Responding to conditions like this in accordance with Government Regulation Number 21 of 2020, the Serdang Bedagai Regency Government has implemented a policy of calling for a ban on learning activities in schools through the Regent's Circular. Serdang Bedagai Number: 18.11/421/1604/220 concerning Prevention of the Spread of Corona Virus Disease (COVID-19).

The call for a ban on carrying out learning activities in schools like this received mixed responses from various education providers, especially at the elementary school level, as happened in Firdaus Village, Sei Rampah District, Serdang Bedagai Regency. There are various attitudes of different actions in carrying out the teaching and learning process carried out by education providers. This greatly affects the opportunities for children to obtain the same education in obtaining education and learning. In addition, the socioeconomic conditions of the families of students who are different from one another are also very influential.

If this condition is not handled seriously, it can have an impact on every child to get the same opportunity for education and teaching as is done in a school environment. In terms of Article 60 paragraph (1) of Law Number 39 of 1999 concerning Human Rights explicitly mandates that every child has the right to receive education and teaching. Realizing the negative impact of the spread of COVID-19 on equal opportunities for every child to receive education and teaching, the Government has firmly determined that the situation for the spread of COVID-19 is an emergency condition for natural disasters in the health sector in Indonesia.

Recognizing the conditions as above, it does not mean the situation of the spread of Covid 19 and the differences in social and economic situations of the existing children's families can be used as a justification for not providing equal opportunities for every child in obtaining education and teaching. For this reason, it is necessary to know what efforts and obstacles were found in fulfilling the right to education and teaching for elementary school children during the spread of COVID-19 in Firdaus Village, Serdang Bedagai Regency. Through discussions like this, various strategies and solutions will be obtained that can be used in fulfilling the right to education and teaching for elementary school children during the current spread of COVID-19. Various existing strategies and solutions are used as input in efforts to fulfill the right to education and learning for elementary school children during the spread of COVID-19 and will be written in the form of scientific articles which will then be published in international scientific article journals.

\section{RESEARCH METHODS}

This legal research used the type of empirical juridical research that intends to show whether children's rights to education during the COVID-19 pandemic can be fulfilled in Firdaus Village, Serdang Bedagai Regency as determined in various applicable legal regulations. As an empirical juridical research, the data used is secondary data sourced from library data and primary data. The data collected were analyzed qualitatively and then the results of the analysis were descriptive to provide answers or descriptions of what was the subject of discussion in this study. 


\section{RESULTS AND DISCUSSION}

\section{Legal Protection for Children to Get Education}

Children are a gift given by Allah SWT as the next generation, not only for families and even nations. Children are expected to be useful in the future for parents. Society and nation. The high expectations that are placed on children do not mean that they do not require adequate preparation. One that must be prepared and fulfilled for children is the opportunity to obtain a proper education.

Juridically, both in the provisions of international law and national law, education is recognized as a form of basic right that must be obtained by every child without exception. Moreover, children's rights to education are an Parents, families, communities, governments, and the state all have a role to play in ensuring, protecting, and fulfilling human rights. Because human rights are nothing but a basic right that must be owned by everyone. (Freaire, 2002, p. 28)

The promotion and protection of children's rights to education can be done through empowerment efforts both constitutionally and institutionally. Empowerment can be done constitutionally by ratifying a number of international human rights instruments, including in the form of laws and presidential decrees. Furthermore, institutional empowerment is carried out by establishing a number of institutions or committees that are under the authority of the state or public private institutions. (Sauri, 2009).

Regarding the understanding of the importance of children's rights to education, it must be returned to the basic principles of fulfilling children's rights, namely non-discrimination, living, growing and developing, in the best interests of children and participating. (Tilaar, 2003 , p. 260). In relation to the role of the state, each country develops obligations, namely to protect, fulfill (to fulfill), and respect (to respect) children's rights. (Social, 2010).

Special protection is a type of protection given to children in specific settings and circumstances in order to provide them with a guarantee of safety from hazards that could jeopardize their growth and development. Children in emergency situations, as defined in Article 59 paragraph (2) letter an of Law Number 35 of 2014, include: a) children who become refugees; b) children who become victims of riots; c) children who become victims of natural catastrophes; and d) children in situations of armed conflict. Efforts that can be undertaken as a result of:

a) Prompt treatment, including treatment and/or rehabilitation physically, psychologically, and socially, not only prevention of disease and other health problems;

b) Psychological and social support for recovery during treatment;

c) Social support for children in disadvantaged families; and

d) Protection and support in all legal proceedings.

\section{The Implementation of Right-Fulfillment to the Education of Elementary School Students in the COVID-19 Pandemic Situation}

The existence of a prohibition policy through school holidays during the COVID-19 period does not mean a cessation of learning activities for students. Moreover, referring to Article 4 paragraph (1) letter b of Government Regulation Number 21 of 2020 that restrictions on activities with school holidays must still consider educational needs. School leave is defined as an interruption in the educational process in 2019, as set out in Rule 9 of the Ministry of Health of the Republic of Indonesia in 2020 on guidelines for large-scale social restrictions related to accelerating the response to Coronacovid disease. doing. Learn at school and use the most effective media to replace the process of teaching and learning at home. Provisions like this still provide opportunities for children to get education and 
teaching services, it's just that the implementation of the teaching and learning process changes which were previously carried out in the school environment and can be replaced outside of school.

To ensure the fulfillment of children's rights to education during the prohibition / school holidays during the COVID-19 pandemic, the government issued various guidelines in the implementation of education and teaching as regulated in various policies and legal provisions as follows:

a. Decree of Ministry of Education and Culture of Republic of Indonesia Number 719/P/2020 regarding Guidelines for Curriculum Implementation in Education Units in Special Conditions.

b. Joint Decree of The Indonesian Ministry of Research, Technology and Higher Education, the Minister of Religious, The Ministry of Health, and The Ministry of Home Affairs: Number 01/KB/2020; Number 516 YEAR 2020; Number HK.03.01/Menkes/363/2020; Number 440-882 YEAR 2020 concerning Guidelines for the Implementation of Learning in the 2020/2021 Academic Year and the 2020/2021 Academic Year During the Corona Virus Disease 2019 (COVID-19) Pandemic Period;

c. Joint Decree of The Indonesian Ministry of Research, Technology and Higher Education, the Minister of Religious, The Ministry of Health, and The Ministry of Home Affairs: Number 03/KB/2021; Number 384 of 2021; Number HK.01.08/ MENKES/ 4242/2O21; Number 440-717 YEAR 2021 concerning Guidelines for the Implementation of Learning During the Corona Virus Disease 2019 (COVID-19) Pandemic;

d. Joint Decree of The Indonesian Ministry of Research, Technology and Higher Education, the Minister of Religious, The Ministry of Health, and The Ministry of Home Affairs: Number 04/KB/2020, Number 737 of 2020; Number HK.01.08/Menkes/7093/2020; Number 420-3987 of 2020 concerning Guidelines for the Implementation of Learning in the 2020/2021 Academic Year and the 2020/2021 Academic Year During the Corona Virus Disease 2019 (COVID-19) Pandemic Period;

e. Circular Letter of The Indonesian Ministry of Research, Technology and Higher Education Number 4 of 2020 regarding implementing education policy when the epidemic of coronavirus disease is needed;

The guarantee of protection provided by such legal provisions is intended so that everyone has the same opportunity and treatment to get an education. Policies need to be established to realize children's right to education, especially during the COVID 19 pandemic. Efforts to Realize Children's Right to Education during the COVID-19 pandemic can be carried out in 2 (two) ways as stated in the various ministerial regulations above, namely:

1) Face-to-face Learning; and or

2) Learning From Home or online.

The determination of the implementation of the learning process that can be used for children during the COVID-19 pandemic is based on a consideration by taking into account the situation in each area in accordance with the zones set by the government, namely:

1) Green zone, meaning: face-to-face learning process in education units can be carried out;

2) Yellow, orange, and red zones: prohibition of carrying out face-to-face learning processes and continuing to learning from home activities. 
The learning process in the green zone can be carried out face-to-face in the school environment unit while still paying attention to, among other things: the readiness of the school to comply with the prerequisites according to the health protocol, and the readiness of students to implement health protocols and maintain physical distancing. For example, school readiness must pay attention to, among other things: the ratio of class conditions and capacity in maintaining a distance between students with the provisions for Elementary Schools of at least 1.5 (one point five) meters and a maximum of 5 (five) students per class, while for Middle Schools / vocational training with a minimum distance of 1.5 (one point five) meters and a maximum of 18 (eighteen) students per class; Number and hours of face-to-face learning by dividing study groups (shifts); obliged to maintain behavior to wear masks, wash hands with soap, maintain distance and maintain cough/sneeze etiquette throughout the education unit environment; school readiness to maintain and ensure the medical condition of the citizens of the education unit.

Based on the Joint Decree Number 04/KB/2020: Number 737 of 2020; Number HK.01.08/Menkes/7093/2020; Number 420-3987 of 2020 in Appendix number IV it is emphasized that the factors that are the basis for considering the implementation of the learning process during the COVID-19 pandemic, among others:

a. the level of risk of spreading COVID-19 in the region;

b. readiness of health service facilities;

c. readiness of the education unit in carrying out face-to-face learning in accordance with the checklist as stated in number XV;

d. access to learning resources/Ease of Learning From Home;

e. psychosocial conditions of students;

f. educational service needs for students whose parents/guardians work outside the home;

g. availability of safe transportation access to and from education units;

$\mathrm{h}$. the residence of the residents of the education unit;

i. mobility of citizens between provinces, between districts/cities, between subdistricts, and between sub-districts/villages; and

j. geographical conditions of the area.

In the event that face-to-face learning cannot be carried out in the school environment, the face-to-face learning process can also be carried out outside the school environment while still implementing health protocols. Although it is possible to organize learning to be carried out face-to-face during the COVID-19 pandemic, parents/guardians of students can choose the implementation of learning to be carried out through learning from home or distance learning.

The implementation of Learning From Home or Distance Learning is intended so that children are not left behind in getting learning opportunities during the COVID-19 period. In order to fulfill children's education rights during the COVD-19 period, a guideline for the implementation of Learning From Home was stipulated in a Circular of the Secretary General of The Indonesian Ministry of Research, Technology and Higher Education Number 15 of 2020).

1. COVID19 To ensure student rights to use educational services in an emergency.

2. Protect the citizens of educational institutions from the negative effects of COVID19.

3. Prevention of the spread and infection of COVID 19 in educational institutions. And

The learning from home process is carried out by taking into account the principles contained in the Circular of The Indonesian Ministry of Research, Technology and Higher Education Number 4 of 2020, namely: 
1. The safety and health of students and educators

2. Home Learning

Activities are conducted to provide students with a meaningful learning experience without the burden of completing all curriculum services.

3. Learn from Home

can focus on teaching life skills, including those related to the COVID 19 pandemic.

4. Include learning materials according to age and educational level, cultural background, personality, and type of student details.

5. Activities and assignments during learning from Home Study will vary by region, unit of education, and student, depending on their interests and conditions, including taking into account the access gap to Home Study facilities. It may be.

6. Student learning outcomes while studying at home receives qualitative and useful feedback from teachers without providing quantitative scores / values. And

7. Facilitates positive interactions and communication patterns between teachers and parents / guardians.

In order to fulfill children's education rights through Learning From Home, the Indonesian Ministry of Research, Technology and Higher Education Number 15 of 2020, this can be carried out in 2 (two) ways, including:

1. Distance learning in the network (online);

2. Distance learning outside the network (offline)

To support the online learning process at home, The Indonesian Ministry of Research, Technology and Higher Education provides several reference sources and media on pages that can be accessed by students through portals and online learning applications using gadgets or laptops. The pages that can be accessed in online learning from home include: Learning House by Pusdatin The Indonesian Ministry of Research, Technology and Higher Education https://learning.kemdikbud.go.id; Educational TV of The Indonesian Ministry of Research, Technology and Higher Education https://tve.kemdikbud.go.id/live/; Digital Learning by Pusdatin and SEAMOLEC The Indonesian Ministry of Research, Technology and Higher Education pusdatin.webex.com; Teacher Sharing http://guruberbagi.kemdikbud.go.id; and others. Meanwhile, offline learning at home can be carried out through: a) television; b) radio; c) Self-study modules and worksheets. d) Printed materials. e) Materials and learning media in and around the object. Through various online and offline learning sources and media like this, it is hoped that children's education rights can be fulfilled. In addition, students using various learning media are expected to increase motivation and eliminate the sense of difficulty in the teaching and learning process during the pandemic.

The Implementation of Right-Fulfillment to the Education of Elementary School Students in the COVID-19 Pandemic Situation through Learning From Home cannot be separated from the role and support of the Education Office, Head of Education Units, and Teachers as the spearhead of successful learning. The Education Office and the Principal coordinate to see and ensure the availability of facilities to support online and offline Learning From Home learning. Meanwhile, the teacher facilitates the implementation of Distance learning is available online, offline, or a combination of both, depending on the conditions and availability of the learning facility. 
The teacher as the spearhead in Learning From Home needs to ensure several things as specified in the Circular of the Secretary General of The Indonesian Ministry of Research, Technology and Higher Education Number 15 of 2020 as follows:

a. Ensuring the learning competencies to be achieved. it is forbidden to Force the completion of the curriculum and focus on developing life skills.

b. Preparing learning materials. In the implementation of Learning From Home,

1) Clean and Healthy Lifestyle (PHBS) and Healthy Community Movement (Germas);

2) recreational activities and physical activities;

3) religious spirituality; and/or

4) strengthening of character and culture.

c. Determing the methods and interactions used

d. Determining learning media type. And

e. Developing teachers abilities

The various national rules above are used as reference materials in the implementation of the learning process for children during the COVID-19 pandemic. Although various kinds of learning models have been determined nationally, their application can be different according to the conditions, abilities and facilities owned. Moreover, each type of media that will be used has strengths and weaknesses, so it is necessary to select the appropriate one. (Rudianto, Muhammad Arifin, Winarti, Muhammad iran Nasution, Khairul Anam, M. Firza Ali, 2020)

Serdang Bedagai Regency in the context of performance of rights of children's education during the COVID-19 pandemic is stipulated in the following provisions:

1. Circular of the Regent of Medium Bedagai Number 18.11/421/1604/220 concerning Prevention of the Spread of Corona Virus Disease (COVID-19)

2. Circular Letter of the Head of the Medium Bedagai Education Office Number 18.11/421/445/220 Regarding the Prevention of the Spread of Corona Virus Disease 19 (COVID 19)

These two circulars provide instructions on how to fulfill children's education rights. in Serdang Bedagai Regency during the school holiday policy during the COVID-19 pandemic. Even though there was a school holiday, the children continued to carry out the learning process from home accompanied by their parents. Principals and teachers facilitate student learning online (online), by utilizing internet facilities (email) or other social media (whatsaap, Facebook). Parents monitor and supervise students In the process of learning at home.

As in several elementary schools in Firdaus Village, Sei Rampah Subdistrict, Serdang Bedagai Regency which became the object of this research, it can be seen that the implementation of the teaching and learning process during the COVID-19 period can still run. Although the Regional Government of Serdang Bedagai Regency has taken a legal policy to close schools as an effort to prevent the spread of COVID-19. Moreover, the Serdang Bedagai Regency area in 2020 to 2021 is categorized in the orange zone at level 3 status. determine the pattern of implementation of Education and learning process for students so that it can be fulfilled.

In general, primary schools in Firdaus Village in Serdang Bedagai Regency use a mixed pattern (hayberd) between offline learning (face to face) and distance learning from home. The offline teaching and learning process is carried out on a limited basis both inside and outside the school environment. The offline (face-to-face) process outside the school is carried out by establishing several posts, the determination of which is based on 
considering the proximity of the students' residences in groups and continuing to apply health protocols.

Likewise, the teaching and learning process in the environment is face-to-face, even though there are restrictions, but there are schools that carry out face-to-face processes in a limited number of students, learning hours and implementing health protocols. This is done by the school based on the consent of the parents. The distance teaching and learning process is carried out online as well as offline learning from home. The use of this learning pattern is adjusted to the facilities and conditions of the students. In general, the online teaching and learning process is delivered through WhatsApp Groups, Zoom and learning videos. As for students with distance learning from home not online, the teaching and learning process is carried out by submitting materials and assignments as well as learning reports to school on a weekly schedule.

The use of this teaching and learning pattern is determined by the school by taking into account the situation of the development of COVID-19 in Serdang Bedagai Regency. In addition, it is also based on suggestions and requests as well as the approval of the parents of students. The implementation of education for children during COVID-19 does not mean that there are no obstacles. The obstacles include: the equipment used in online learning is generally still shared in one family and learning outcomes are not complete due to limited offline and online meeting time. So that it affects the fulfillment of children's education rights to the fullest.

\section{CONCLUSION}

The government has guaranteed the implementation of right-fulfillment to the education of elementary school students in the COVID-19 pandemic situation. The government provides several guidelines that can be used in the learning process as an effort to fulfill children's education rights: Likewise in the Serdag Bedagai Regency, children's education rights have also received attention from the local government. The fulfillment of the education rights of elementary school children in Firdaus Village, Sei Rampah Subdistrict, Serdang Bedagai Regency is carried out through, namely: learning from home in the form of during and offline or a combination of both. However, the government still provides the possibility to conduct limited face-to-face learning by taking into account the fulfillment of the conditions that must be met as determined.

\section{REFERENCES}

Andriado, I., Rahmatillah, H. Z., Nisa, A. K., \& Purwasih, J. H. G. (2021). Corona Wedi Buto: Myth in the Efforts of the Tanggulwelahan Villager Facing Covid-19. Randwick International of Social Science Journal, 2(2), 75-85. https://doi.org/10.47175/rissj.v2i2.217

Bachtiar. (2018). Metode Penelitian Hukum, Pamulang- Tanggerang Selatan, UNPAM PRESS.

Fuady, I., Sutarjo, M. A. S., \& Ernawati, E. (2021). Analysis of Students' Perceptions of Online Learning Media During the Covid-19 Pandemic (Study of E-learning Media: Zoom, Google Meet, Google Classroom, and LMS) . Randwick International of Social Science Journal, 2(1), 51-56. https://doi.org/10.47175/rissj.v2i1.177

Har, Tilaar. (2003). Kekuasaan dan Pendidikan Suat Tinjaun dari Prespektif Studi Kultural, Magelang, Indonesia.

Marzuki, P.M. (2017). Penelitian Hukum, (13 th ed)", Jakarta, Kencana. 
Nurul, Zuriah. (2007). Metodelogi Penelitian Sosial dan Pendidikan Teori-Aplikasi, Jakarta, Bumi Aksara.

Syamsudin, M. (2007). Operasionalisasi Penelitian Hukum.Jakarta: RajaGrafindo Persada

Paulo, Freaire. (2002). Politik Pendidikan. Kebudayaan, Kekuasan dan Penindasan, Yogyakarta, Pustaka Peajar.

Disantara, Fradhana Putra. (2020). Tanggung Jawab Negara Dalam Pandemi COVID-19, Jurnal Cedikia Hukum, 6 (1), hlm. 49-51.

Harisman. (2020). Perlindungan Hukum Bagi guru Dalam Menjalankan Tugas Pendidikan Dan Pengajaran. De Lega Lata Jurnal Ilmu Hukum, 5 (1),

Pasaribu, Asbin. (2017). Implementasi Manajemen Berbasis Sekolah dalam Pencapaian Tujuan Pendidikan Nasional di Madrasah., Jurnal Edu Tech, 3 (1),

Sholahudin, Umar. (2017). Pendekatan sosiologi Hukum Dalam Memahami Konflik Agraria. Jurnal Dimensi, November, 10 ( 2),

Supriyadi. (2020). Kebijakan Penanganan COVID-19 Dari Perspektif Hukum Profetik. Suloh Jurnal Program Studi Megister Hukum. Edisi Khusus,

Windari, Mei Tatik. (2012). Pemenuhan Hak Pendidikan Anak Didik Pemasyarakatan Di Lembaga Pemasyrakatan Anak. DIH, Jurnal Ilmu Hukum, 8 (5).

Sauri, Sofyan. (2009), (2021, 9 February). Hak Anak Mendapatkan Pendidikan, diakses dari http://sofyansauri.lecturer.upi.edu/hak-anak-mendapatkan-pendidikan/, 